\title{
PREDICTION OF VENTURI SCRUBBER PERFORMANCE
}

\author{
Mofreh H. Hamed and A. A. Abdel-Hamied \\ Department of Mechanical Power Engineering, \\ Faculty of Engineering, Minufiya University, \\ Shebin El-Kom, Egypt
}

\begin{abstract}
$\underline{\text { ABSTRACT }}$
The particle collection venturi performance is achieved at the expense of pressure drop through it. The accurate prediction of pressure drop and collection efficiency is vital to the optimum design of these systems to achieved required environmental standards. Performance of venturi scrubbers has been investigated theoretically and expressed in terms of pressure drop and collection efficiency. The theoretical model comprises simultaneous differential equations for particle concentration, droplet motion and momentum exchange. Also in this model the collection efficiency is predicted based on the inertial impaction, diffusion and interception mechanisms. Pressure drop and collection efficiency predictions of this model and previous models are compared with published experimental data. The results show that the present model have been validated against previously published experimental data and gives significantly improved predictions compared with the previous models.
\end{abstract}

\section{NOMENCLATURE:}

$\begin{array}{lll}\text { A } & \text { area } & \mathrm{m}^{2} \\ \mathrm{C} & \text { concentration } & \mathrm{mg} \cdot \mathrm{m}^{-3} \\ \mathrm{C} & \text { Cunnighom factor } & - \\ \mathrm{C}_{\mathrm{D}} & \text { drag coefficient } & - \\ \mathrm{d} & \text { diameter } & \mathrm{m}\end{array}$

\footnotetext{
Manuscript received from $\mathrm{Dr}$. Mofreh $\mathrm{H}$. Hamed

Accepted on : 7/5/2001

Engineering Research Journal Vol 24,No 3, 2001 Minufiya University, Faculty Of Engineering, Shebien EI-Kom, Egypt, ISSN 1110-1180
} 


$\begin{array}{ll}\mathrm{D}_{\mathrm{e}} & \text { equivalent diameter } \\ \mathrm{f} & \text { friction coefficient } \\ \mathrm{k} & \text { Boltzman constant } \\ \mathrm{H} & \text { total length of venturi } \\ \mathrm{L} & \text { throat fength } \\ \mathrm{m} & \text { mass flow rate } \\ \mathrm{n}_{\mathrm{c}} & \text { number of collectors (droplets) } \\ \mathrm{p} & \text { pressure } \\ \mathrm{Pe} & \text { Peclet number } \\ \mathrm{Q} & \text { flow rate } \\ \mathrm{R} & \text { diameter ratio } \\ \mathrm{Re} & \text { Reynolds number } \\ \mathrm{Stk} & \text { Stock number } \\ \mathrm{t} & \text { time } \\ \mathrm{T} & \text { absolute gas temperature } \\ \mathrm{u} & \text { gas velocity } \\ \mathrm{V} & \text { velocity } \\ \mathrm{V}_{\mathrm{r}} & \text { relative velocity }\end{array}$

$\mathrm{m}$

-

J. $\mathrm{K}^{-1}$

m

m

$\mathrm{kg} \cdot \mathrm{s}^{-1}$

droplet. $\mathrm{m}^{-3}$

$\mathrm{Pa}$

$\mathrm{m}^{3} \cdot \mathrm{s}^{-1}$

$-$

$-$

-

S.

K

$\mathrm{m} \cdot \mathrm{s}^{-1}$

$m \cdot s^{-1}$

$m . s^{-1}$

\section{GREEK SYMBOLS:}

$\beta_{2} \quad$ divergent section angle

deg.

$\eta \quad$ efficiency

$\wp \quad$ particle diffusivity

$\mu \quad$ dynamic viscosity

$\mathrm{m}^{2} \cdot \mathrm{s}^{-1}$

N.s.m ${ }^{-2}$

$\rho$ density

\section{SUBSCRIPTS:}

$\begin{array}{ll}\text { c } & \text { collector } \\ \text { d } & \text { droplet } \\ \text { D } & \text { diffusion } \\ \mathrm{g} & \text { gas } \\ \text { I } & \text { inertial impaction } \\ \text { int } & \text { interception } \\ \text { l } & \text { liquid } \\ \text { p } & \text { particle } \\ \text { t } & \text { throat }\end{array}$

\section{INTRODUCTION}

Venturi scrubbers are considered as one of the effective devices for collecting fine particles, usually smaller than 2 to $3 \mu \mathrm{m}$ in diameter, from dusty gases. They are particularly suitable for the sticky, flammable or highly 
corrosive particulate matter. Venturi scrubber performance for a particular application may be characterized by collection efficiency and pressure drop.

The high performance of the Venturi scrubbers is achieved by accelerating the gas stream to very high velocities, of the order of $60-120 \mathrm{~m} / \mathrm{s}$. The liquid droplet generally introduced uniformly at the throat inlet through several lowpressure spray nozzles.

The droplets accelerate in the throat section and due to the velocity difference between the particles and the droplets, the particles are impacted against the slow moving droplets. This acceleration of the droplets is not likely to be completed at the end of the throat, so that particle collection continues to some extent into the divergence section of the venturi. The gas liquid mixture is then directed to a collection device such as a cyclone separator where the droplets carrying the particulate matter are separated from the gas stream.

Efforts were made to determine and simulate the pressure drop and collection efficiency in the venturi scrubber as in [1-7]. Some investigators $[3,6]$ studied the mechanisms of particulate collection in venturis. They reported that, there are three mechanisms contributing in the collection process through the venturi scrubber. These mechanisms are the inertial impaction, diffusion, and interception. In their work they used only the inertial impaction mechanism in predicting the collection efficiency. These methods describe the collection process by neglecting a number of influencing factors, so that they give only qualitatively correct results.

The pressure drop through a venturi scrubber is considered as an important parameter for determining the scrubber performance. This pressure drop may classified into five components namely, fractional pressure drop, acceleration pressure drop of the gas, acceleration pressure drop of the droplet, acceleration pressure drop of the film and gravitational pressure drop, as in Ref. [4]. The accuracy of calculation of the pressure drop depends mainly on choosing the suitable correlation's to determine the droplet size, drag force on the droplet and friction factor to estimate the fractional pressure drop. There are several correlation's available, both theoretical and experimental, for the prediction of pressure drop in a venturi scrubber. Calvert [1], derived the simple equation for determining the pressure drop as:

$$
\Delta \mathrm{p}=\rho_{1} \mathrm{v}_{1}^{2} \frac{\mathrm{Q}_{1}}{\mathrm{Q}_{\mathrm{g}}}
$$

Researchers have continued to seek improvements on this simplistic model which is still used in industry. Therefore, Yung et. al. [6] modified Calvert's equation taking into accounts the fact that the liquid droplets are not fully accelerated to the gas velocity in the throat. They neglected the pressure loss due to the wall friction and gas pressure recovery in the divergent section.

$$
\Delta \mathrm{p}=2 \beta \rho_{1} \mathrm{v}_{\mathrm{g}}^{2}\left(\frac{\mathrm{Q}_{\mathrm{I}}}{\mathrm{Q}_{\mathrm{g}}}\right)
$$

Where, 


$$
\begin{aligned}
& \beta=\left(1-x^{2}+\sqrt{\left(x^{4}-x^{2}\right)}\right) \\
& x=\frac{3 L_{1} C_{D 1} \rho_{g}}{16 d_{c} \rho_{1}}+1
\end{aligned}
$$

Because of the more accurate pressure drop predictions are limited, Boll [7] developed a systematic approach based on simultaneous solution of the equations of drop motion and momentum exchange. He used only the frictional pressure drop and acceleration pressure drop of the droplet to estimate the total pressure drop through the venturi. Furthermore, Leith et al. [8] take into account the pressure drop recovery due to the decelerating of droplets in the diffused section. Their equation is,

$$
\Delta \mathrm{p}=\rho_{1} \mathrm{v}_{\mathrm{t}}^{2} \frac{\mathrm{Q}_{1}}{\mathrm{Q}_{\mathrm{g}}}\left[\beta\left(1-\frac{\mathrm{v}_{\mathrm{gf}}}{\mathrm{v}_{\mathrm{t}}}\right)+\left(\frac{\mathrm{v}_{\mathrm{gr}}}{\mathrm{v}_{\mathrm{t}}}\right)^{2}\right]
$$

Where, $v_{\mathrm{gt}}$ is the exit duct velocity.

Based on the above discussion, it can be observed that the proposed equations by Calvert [1], Yung et al [6] and Boll [7], were derived from the equations of motion and momentum balance with neglecting the effect of gravity on the droplet motion and some components of pressure drop.

From the forgoing considerations, it is evident that more efforts are required to modify both theories that treat the mechanism of particle collection in venturi scrubbers. Also from this literature, it is noticed that the venturi scrubber performance is achieved at the expense of pressure drop through the venturi. The accurate prediction of pressure drop and collection efficiency is vital to the optimum design of these systems in order to achieve the required environmental standards. In order to describe accurately the physical phenomena occurring in a venturi scrubber, the main objective of this paper is to study theoretically the venturi scrubber performance, taking into consideration different forces and mechanisms of solid particles collection that affect this performance,

\section{THEORETICAL ANALYSIS}

The performance of venturi scrubber is specified in terms of collection efficiency and pressure drop. The overall collection efficiency of a venturi scrubber can be modeled using the following assumptions:

i- well-mixed conditions at any value of y, Fig. (1).

ii- slip ratio between air and solid particles is unity.

iii- if a small particle impacts a large droplet, it will stick and to be removed from the gas stream. 


\section{$\underline{2.1 \text { Particle concentration }}$}

Based on the above assumptions considering a small element with dimensions $\Delta y$ and unit depth, as shown in Fig. (1), the mass conservation equation is:

$$
c_{y} u_{g} A-c_{y+\Delta y} u_{g} A=\Delta m
$$

Where, $\Delta \mathrm{m}$ is the rate of mass of the collected particles, which can be calculated, from the following equation:

$$
\Delta \mathrm{m}=\eta_{\mathrm{d}} \mathrm{v}_{\mathrm{r}} \mathrm{c}_{\mathrm{y}} \frac{\pi}{4} \mathrm{~d}_{\mathrm{c}}^{2} \mathrm{n}_{\mathrm{c}} \mathrm{A} \Delta \mathrm{y}
$$

Where, $n_{\mathrm{c}}$ is the number of collecting (droplets) per unit volume of gas:

$$
\mathrm{n}_{\mathrm{c}}=\frac{6 \mathrm{Q}_{1}}{\pi \mathrm{d}_{\mathrm{c}}^{3} \mathrm{v}_{\mathrm{c}} \mathrm{A}}
$$

and $\eta_{\mathrm{d}}$ is the single droplet efficiency.

The single droplet efficiency plays an important role in the calculation of the collection efficiency and the change of the particle concentration in the venturi scrubber. A general form of the single droplet efficiency must include the effects of impaction, diffusion and interception mechanisms. Licht, [9], proposed the following scheme to evaluate the single droplet efficiency involving the previous effects:

$$
\eta_{\mathrm{d}}=1-\left(1-\eta_{\mathrm{I}}\right)\left(1-\eta_{\mathrm{D}}\right)\left(1-\eta_{\text {Int }}\right)
$$

The collection efficiency by interception of droplet may be calculated through the following expression as in Ref.[9],

$$
\eta_{\mathrm{int}}=(1+\mathrm{R})^{2}-3(1+\mathrm{R}) / 2+1 /(1+\mathrm{R}) \approx 3 \mathrm{R}^{2} / 2
$$

Where, $\mathrm{R}$ is the particle collector diameter ratio and defined by,

$$
R=\frac{d_{p}}{d_{c}}
$$

The collection efficiency by inertial impaction is given by [10], as,

$$
\eta_{1}=\left[\frac{\mathrm{Stk}}{\mathrm{Stk}+0.07}\right]
$$

Where, Stk is the Stock number which is defined by, Stk $=\frac{\rho_{p} d_{p}^{2} v_{r}}{18 \mu_{g} d_{c}}$

The collection efficiency by diffusion can be obtained from [9], as,

$$
\eta_{1},=4.18 \operatorname{Re}^{0.17} \mathrm{Pe}^{0.66}
$$


Where, $\mathrm{Pe}$, is the Peclet number, $\mathrm{Pe}=\frac{\mathrm{v}_{\mathrm{r}} \mathrm{d}_{\mathrm{c}}}{\wp}$ and $\wp$ is the particle diffusivity and given by $\wp=\frac{\mathrm{kTC}}{3 \pi \mu_{\mathrm{g}} \mathrm{d}_{\mathrm{p}}}$, while $\mathrm{Re}$, is the Reynolds number based on the relative velocity and collector diameter.

Combining Eq. (4) and Eq. (5) gives

$$
c_{y} u_{a} A-\left(c_{y}+\frac{\partial c_{y}}{\partial y} \Delta y\right) u_{a} A=\eta_{d} v_{r} c_{y} \frac{\pi}{4} D_{c}^{2} n_{c} A \Delta y
$$

Rearranging and using definition of gas flow rate, $\mathrm{Q}_{\mathrm{g}}=\mathrm{u}_{\mathrm{g}} \mathrm{A}$, we obtain,

$$
\frac{d c}{c}=-\eta_{d} \frac{v_{r}}{v_{c}} \frac{3}{2 d_{c}}\left(\frac{Q_{1}}{Q_{g}}\right) d y
$$

\subsection{Droplet yelocity}

The collector velocity plays an important role in determining the particle concentration through the venturi and consequently, the collection efficiency. The collector velocity $\left(v_{c}\right)$ increases from $v_{c}(0)$ at the throat inlet to reach the gas velocity at some point downstream of the injection inlet. At any point downstream of the inlet, the collector velocity $\left(\mathrm{v}_{\mathrm{c}}\right)$, can be calculated by solving the equation of motion as in Ref.[11],

$$
\left.\frac{d v_{c}}{d t}=g-\left(\frac{3 C_{D}}{4}\right) \frac{\rho}{\rho_{c} d_{c}}\right)\left[v_{c}(y)-v_{g}\right]
$$

Where, $C_{D}$ is the drag coefficient and can be calculated by [12],

$$
C_{D}=0.4+\frac{24}{\operatorname{Re}}+\frac{6}{\left[1+\operatorname{Re}^{\frac{1}{2}}\right]}
$$

Equation (13) is solved using a step-wise numerical integration method in which the collector velocity and location will be computed at the end of a small interval of time $t$.

An important parameter in predicting the dust collection efficiency is the droplet size generated in the venturi. The diameter of the droplet, obtained from the liquid atomization in the venturi throat, can be evaluated according to [13] as,

$$
\mathrm{d}_{\mathrm{c}}=\frac{5000}{\mathrm{v}_{\mathrm{T}}}+31.2\left(\frac{\mathrm{Q}_{1}}{\mathrm{Q}_{\mathrm{g}}}\right)^{1.5}
$$

Where, $d_{c}$ is in $\mu \mathrm{m}$, 


\subsection{Pressure drop}

The pressure drop through a venturi scrubber is due to the friction loss along the wall of the scrubber, acceleration of gas and liquid droplets. Friction loss depends largely on the geometry of the scrubber. Acceleration losses, which are predominant in the venturi scrubber pressure drop, are fairly intensive to scrubber geometry.

A momentum balance is written over the control volume of small length $\Delta y$ as shown in Fig. (1), in a manner analogous to the material balance

$$
A d p+m_{g} d v_{g}+m_{1} d v_{c}+\left(1+\frac{m_{1}}{m_{g}}\right) \frac{A \rho_{g} f v_{g}^{2}}{2 D_{e}} d y=0
$$

Where, the last term represents wall friction based upon equivalent diameter, $D_{e}$ of the venturi, and upon the turbulent friction factor, f. To obtain the total pressure drop, Eq. (16) should be integrated numerically from $y_{0}$ to $y_{3}$.

\section{RESULTS AND DISCUSSION}

The results of this investigation are discussed in terms of half divergence angle, liquid gas volume rate ratio, throat length, position of injection of liquid, pressure drop, collection efficiency and comparisons to proposed pressure drop model and collection efficiency. In the theoretical results the injection of liquid has different locations along the scrubber axis, the droplet diameter is calculated using Eq. (15), the friction factor was 0.027 , as in [7] and the effect of the gravity on the droplet velocity is taken into consideration, Eq. (13).

\section{3-1 Effect of divergence angle, $\left(\boldsymbol{\beta}_{2}\right)$ :}

Figure (2) shows the variation of axial pressure drop, droplet velocity, gas droplet velocity ratio and collection efficiency at different values of halfdivergent angles, $\left(\beta_{2}=1.5^{\circ}, 2.5^{\circ}, 3.5^{\circ}\right.$ and $\left.4.5^{\circ}\right)$. It can be seen from Fig. (2.a) that the pressure drop along the scrubber axis increases through the convergent and throat parts but it decreases through the divergent part. The rate of increasing of pressure drop in the convergent part is faster than that in the throat. This is because the friction pressure drop increases rapidly in the convergent part. It is clear also from this figure that, in the convergent and throat sections the examined parameters (axial pressure drop, droplet velocity, gas droplet velocity ratio and collection efficiency) are not affected by the change of divergent angle, $\beta_{2}$. Also it can be noticed that the pressure drop increases with decreasing the divergent angle. The droplet velocity and collection efficiency increase through the throat and divergent parts and decrease with increasing the divergent angle, as shown in Fig. (2. b, d). While 
the velocity ratio, decreases along the scrubber axis and increases with decreasing the divergent angle $\beta_{2}$, as shown in Fig. (2.c).

\section{3-2 Effect of liquid gas ratio $Q_{L} / Q_{\mathrm{g}}$ :}

The effect of the volume flow rate ratio $\left(\mathrm{Q}_{1} / \mathrm{Q}_{\mathrm{g}}\right)$ on the examined parameters at a particle diameter $d_{p}=1.0 \mu \mathrm{m}$ has been presented in Fig. (3.a, b, $c$ and $d$ ). From this figure it can be seen that the examined parameters at constant value of $y$, increase with increasing the liquid gas volume rate ratio, Fig. (3.a, c and d), while the droplet velocity decreases as shown in Fig. (3.b). This tendency can be explained as, with increasing the ratio of $Q_{1} / Q_{g}$, the number of droplets (target) and the droplet diameter, given by equations (6) and (15) respectively, are increasing. This tends to increase the collecting surface area and the gravity force becomes more effect on the droplet motion. Therefore, the collection efficiency and velocity ratio are increasing while the droplet velocity decreases. It is also predicted from Fig. (3. $\mathrm{a}, \mathrm{b}$ and $\mathrm{c}$ ) that as the liquid gas volume rate ratio has small values, its effect on axial pressure drop, droplet velocity and gas droplet velocity ratio will be decreased. While, in Fig. (3.d) increasing the liquid gas volume rate ratio will cause a small effect on the collection efficiency.

\section{3-3 Effect of throat length, $L$ :}

The effect of throat length on the change of examined parameters along venturi scrubber is shown in Fig. (4). These results are carried out at constant values of the other venturi parameters, such as, convergent length, divergent length, $\beta_{1}, \beta_{2}$ and liquid gas ratio. This figure illustrates that the examined parameters increase with increasing the throat length at constant value of $y$. This behaviour; is due to that the droplet velocity is approaching the gas velocity and consequently, the relative velocity is decreasing. This leads to an increase the collection efficiency.

\section{3-4 Effect of injection position. (y):}

The variation of pressure drop, collection efficiency and droplet diameter as a function of liquid entrance position is shown in Fig. (5). The results have been obtained based on $\mathrm{Eq}$. (15) for determining droplet diameter at constant value of $\mathrm{Q}_{\mathrm{l}} / \mathrm{Q}_{\mathrm{g}}=1.0 \mathrm{lit} / \mathrm{m}^{3}$ and initial droplet velocity, $\mathrm{v}_{\mathrm{c}}(0)=5.0$ $\mathrm{m} / \mathrm{s}$. From this figure it can be seen that the collection efficiency and pressure drop are decreasing when the entrance position of liquid is located upstream of the throat inlet while the droplet diameter increases. This is because any decrease in relative velocity tends to increase the droplet diameter and decreasing the collecting surface area and consequently, decreasing the collection efficiency. 


\section{3-5 Model validation:}

To validate and verify the applicability of this model that may be used in industry, three comparisons were carried out. First comparison concerns with the change of pressure drop along the scrubber as shown in Fig. (6). This figure illustrates a comparison between the present theoretical model and experimental published results. Calculations of pressure drop along venturi scrubber have been carried out and the results are compared with the published data of Allen et. al. [5] and Boll [7]. The pressure drop is expressed in terms of the gas velocity head at the throat:

$$
\frac{\Delta \mathrm{p}}{\Delta \mathrm{p}_{1}}=\frac{\Delta \mathrm{p}}{\frac{1}{2} \rho_{\mathrm{g}} \mathrm{u}_{\mathrm{g}}^{2}}
$$

Comparisons in Fig. (6) reveal that the present model predictions have a good agreement with the published data [5]. The second comparison presents a comparison between the different theoretical models of $[1,7$ and 8], published data, [5] and the present model as shown in Fig. (7). This figure indicates that the present model is more agreement with experimental data than other theoretical models. Also, from this figure it can be noticed that Calvert's equation, Eq. (2), predicts a higher-pressure drop than those experimentally measured and other models except at low liquid flow rates, where only the gas frictional losses are significant. Calvert's model [1] neglects the wall friction and the pressure recovery in the diffuser and assumed that all liquid droplets were accelerated to the gas velocity in the throat. Furthermore, Yung et. al. [6] modified Calvert's equation considering that the liquid droplets are not fully accelerated to the gas velocity in the throat. Therefore, Calvert's equation, Eq. (2), predicts a high deviation with the experimental data and present model.

For more validation of the present model, the third comparison between the variation of the predicted collection efficiency and the experimental published data of Allen [14] with particle diameter is achieved as shown in Fig. (8). The calculation were carried out at constant values of $\Delta p$ $(600.0 \mathrm{~Pa})$ and $\left(\mathrm{Q}_{1} / \mathrm{Q}_{\mathrm{g}}=1.0, \mathrm{lit} / \mathrm{m}^{3}\right)$ and using Eq. (8) to calculate the single droplet efficiency. Finally, it is clear that the comparison provides a good agreement between the present model and the experimental data.

\section{CONCLUSIONS}

From the above discussion, the following results can be concluded:

1. The pressure drop and collection efficiency increase with increasing the throat length and liquid gas ratio and decrease with increasing the half divergence angle of venturi.

2. The predicting of collection efficiency based on the different collection mechanisms is more accurate. 
3. The droplet velocity is very important factor in predicting venturi scrubber performance.

4. The results clearly indicate that the present model provides a good agreement with the experimental data.

\section{REFERENCES:}

1. Calvert S.," Source Control by Liquid Scrubbing" in A.C.Stern, Ed., Air Pollution, Academic Press, New York, (1968).

2. Viswanathan, S.," Examination of Liquid Film Characteristics in the Prediction of pressure Drop in a vanturi Scrubber" Chem. Engng Sci. Vol. 53, Pp. 3161-3175, (1998).

3. Viswanathan, S.," Development of a Pressure Drop Model for a Variable Throat Venturi Scrubber" Chem. Engng. J. Vol. 71, pp. 153-160, (1998).

4. Pulley, R. A. " Modelling the Performance of Venturi Scrubbers" Chem. Engng. J., Vol. 67, pp. 9-18, (1997).

5. Allen, R. W. K. and Santen, A. Van, "Designing for Pressure Drop in Venturi Scrubbers: the Importance of Dry Pressure Drop" Chem. Engng. J., Vol. 61, pp. 203-211, (1996).

6. Yung, S.C., Barbarika F. And Calvert S." Pressure Loss in Venturi Scrubbers" J. Air Pollution Control Association, Vol. 27, No. 4, pp.-348351, (1977).

7. Boll, R. H. "Particle Collection and Pressure Drop Venturi Scrubbers" Ind. Eng. Chem. Fundam., Vol. 12, No. 1, pp. 40-50, (1973).

8. Leith, D., Cooper, D. W. and Rudnick, S.N." Venturi Scrubbers: Pressure Loss and Regain" Aerosol Sci. Technol., Vol. 4, (2), pp. 239-243, (1985).

9. Licht, W." Air Pollution Control Engineering: Basic Calculations for Particulate Collection" Marcel Deker, New York, (1980).

10. Calvert, S. And Englund, H. M., " Handbook for Air Pollution Technology" John Wiley \& Sons, New York, (1984).

11. Tsuji, Y., Morikawa, Y., Tanaka, T., Nakatsukasa, N., and Nakatani, M.," Numerical Simulation of gas Solid Two -Phase Flow in a Two Dimensional Horizontal Channel", Int. J. Multiphase Flow, Vol. 13, No. 5, pp. 671-684, (1987)

12. Kladas, D.D., And Deorgiou, D. P., "A Relative Examination of $C_{D}-\operatorname{Re}$ Relationships Used in particle Trajectory Calculations" ASME J. Of Fluids Engineering, Vol. 115, Pp. 162-165, (1993).

13. Rao, C. S.," Environmental Pollution Control Engineering" New Age International, New Delhi, Sixth Edition, (1998).

14 Allen, R. W. K.," Prediction of Venturi Scrubber Grade Efficiency Curves Using the Contacting Power Law" Powder Technology, Vol. 86, pp. 137144, (1996). 


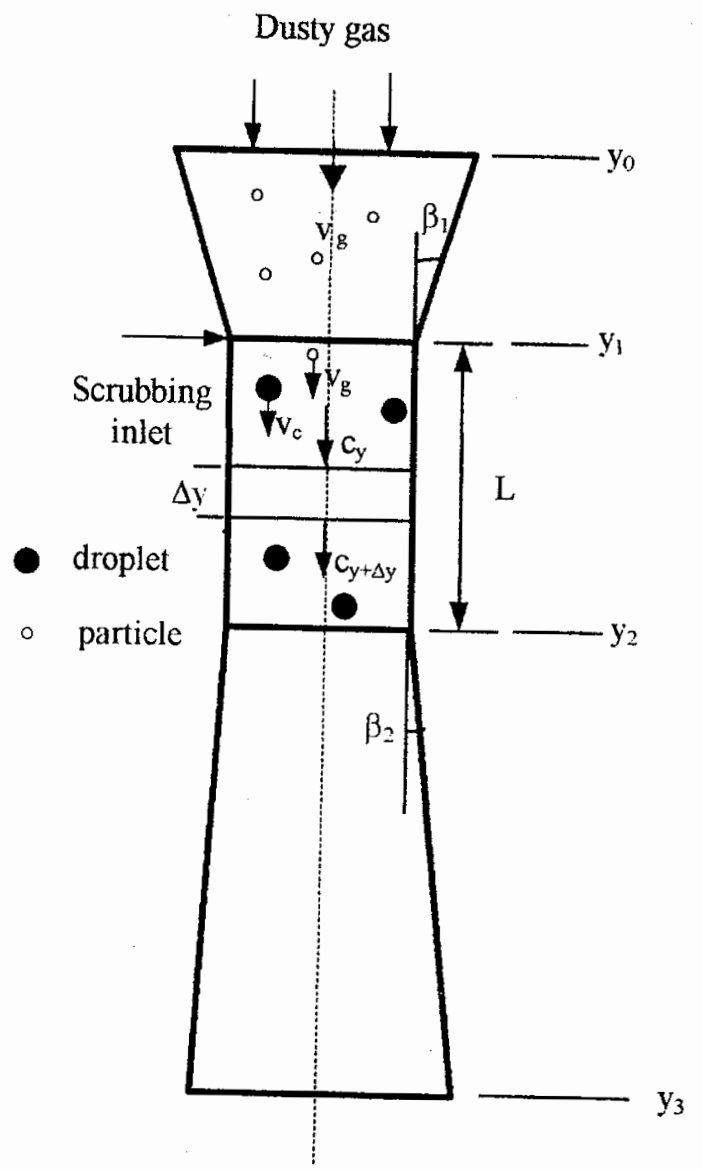

Fig. (1) Venturi Scrubber Geometry. 


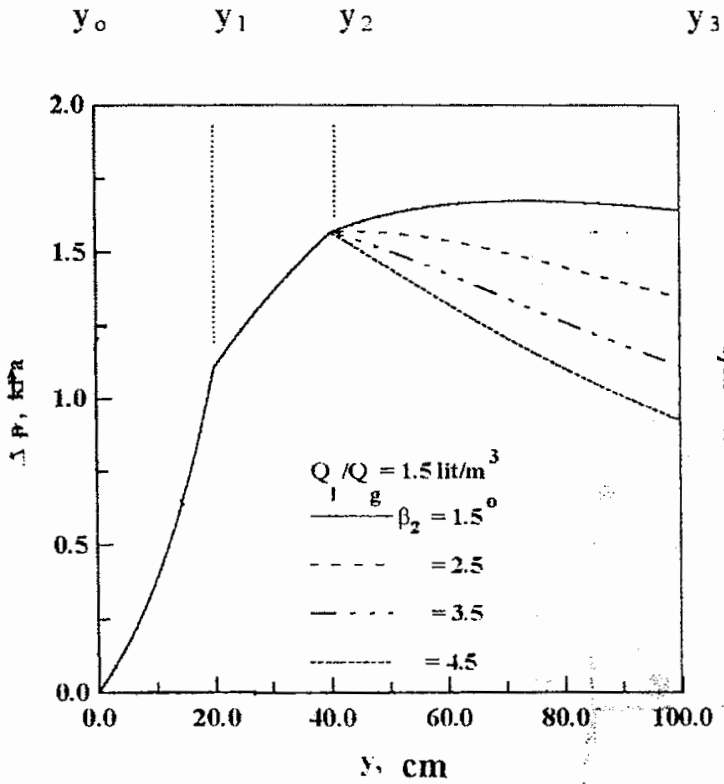

(a)

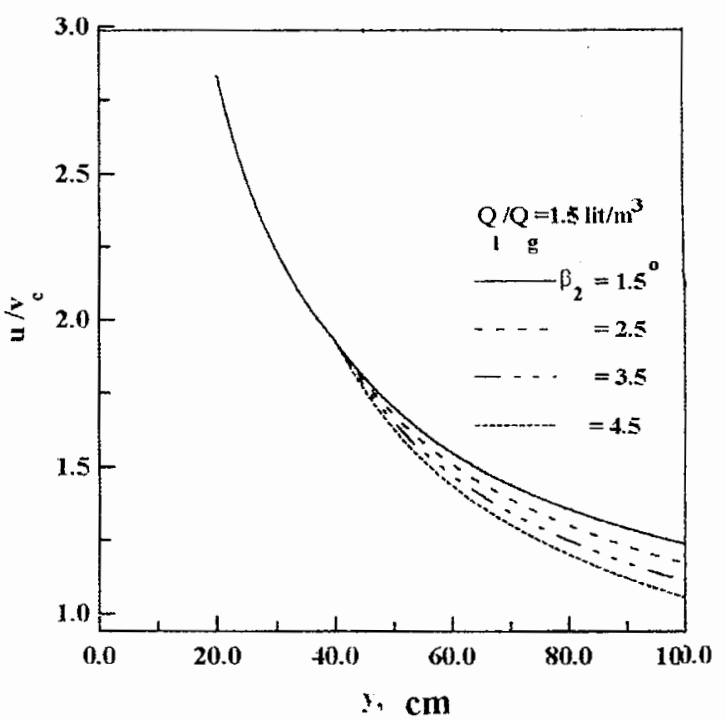

(c)

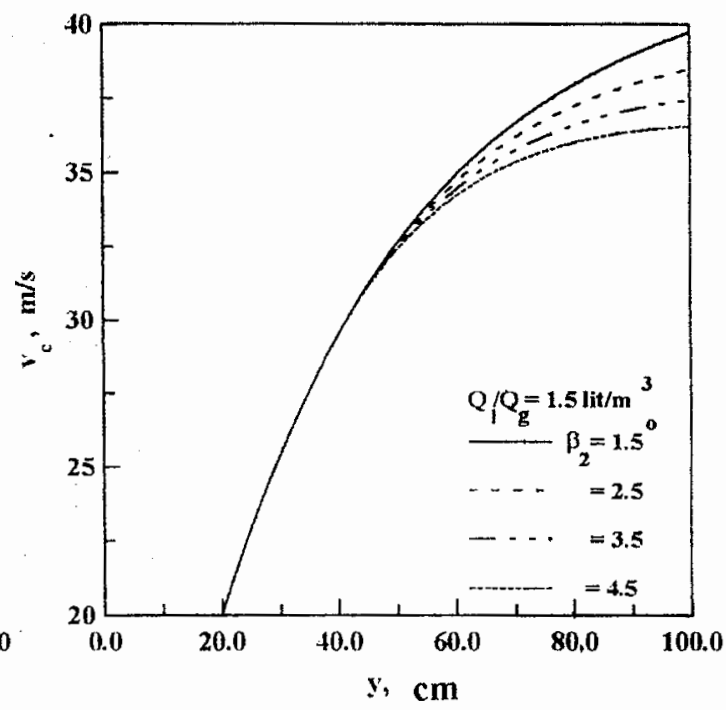

(b)

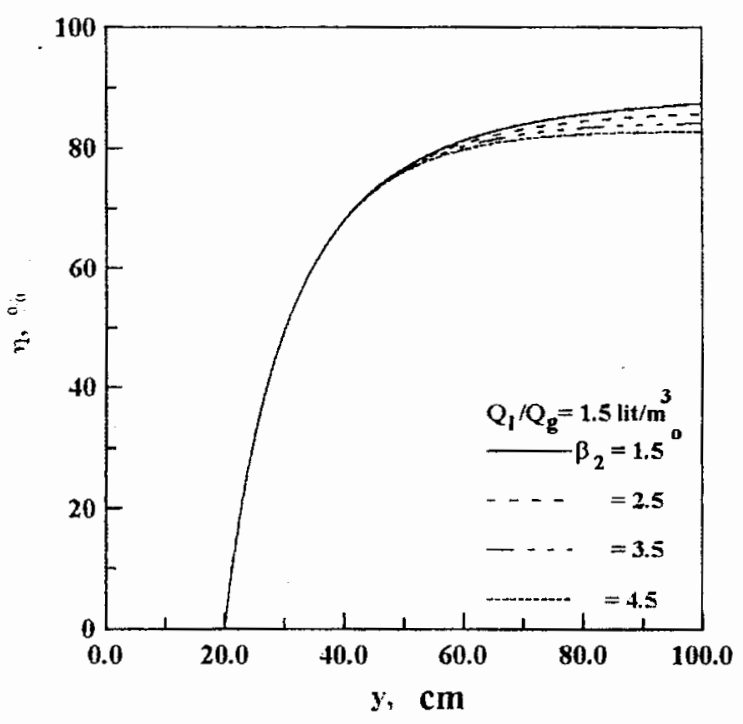

(d)

Fig. (2) Variation of axial pressure drop, droplet velocity, velocity ratio and collection efficiency along the scrubber axis at different of values of $\beta_{2}$. 


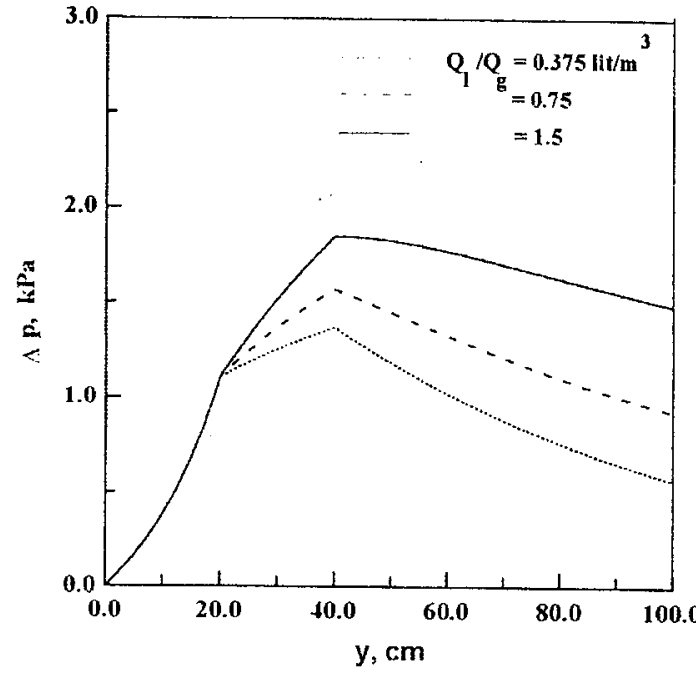

(a)

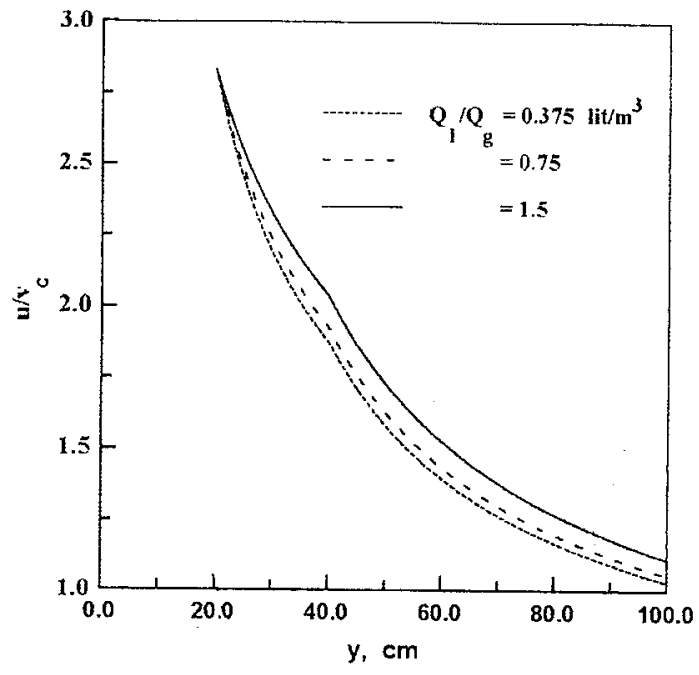

(c)

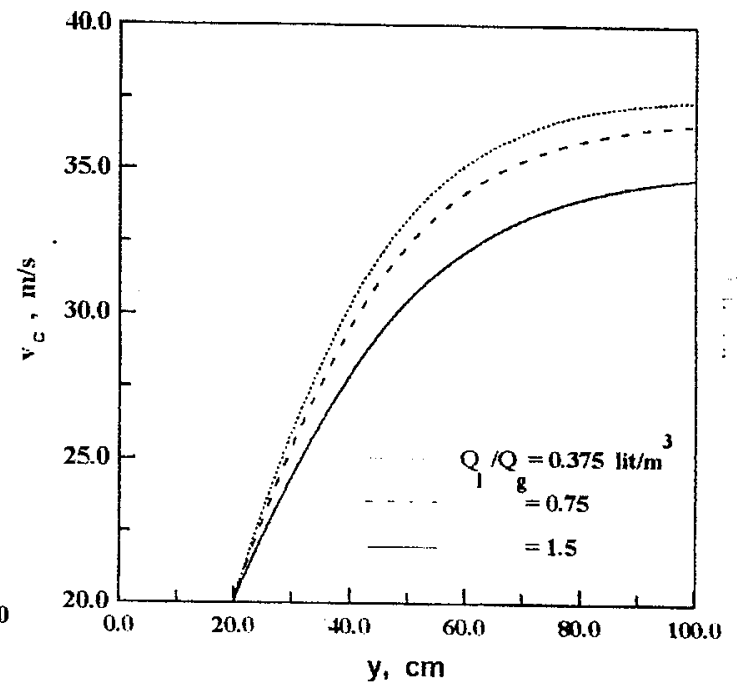

(b)

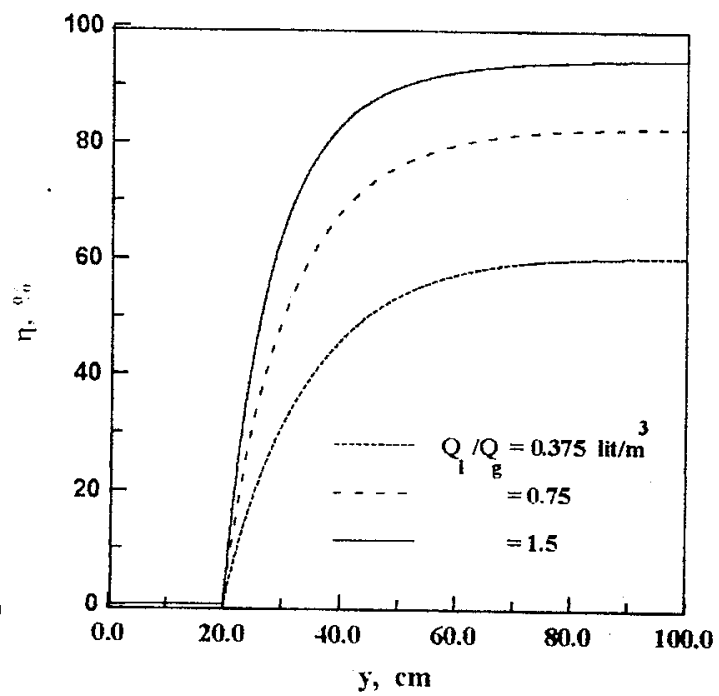

(d)

Fig. (3) Variation of axial pressure drop, droplet velocity, velocity ratio, and scrubber efficiency along the scrubber axis at different of values of $Q_{/} / Q_{g}$. 


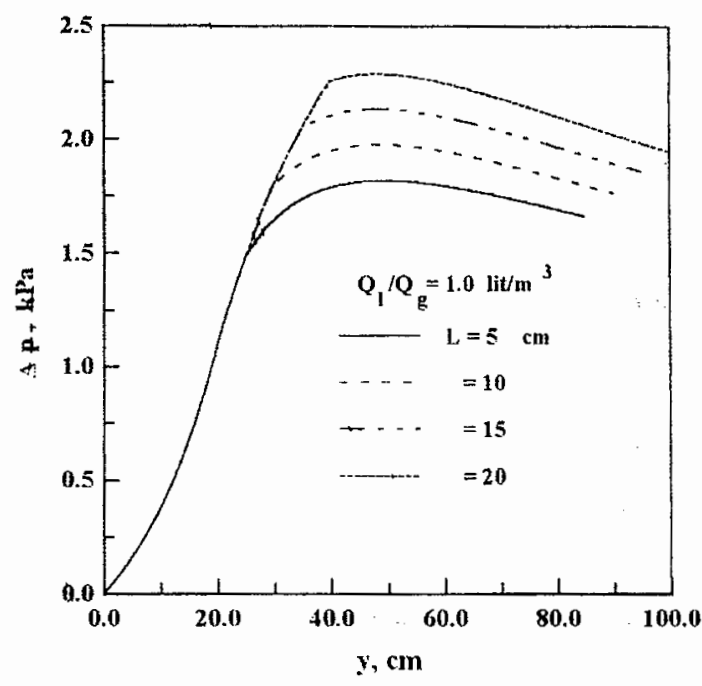

(a)

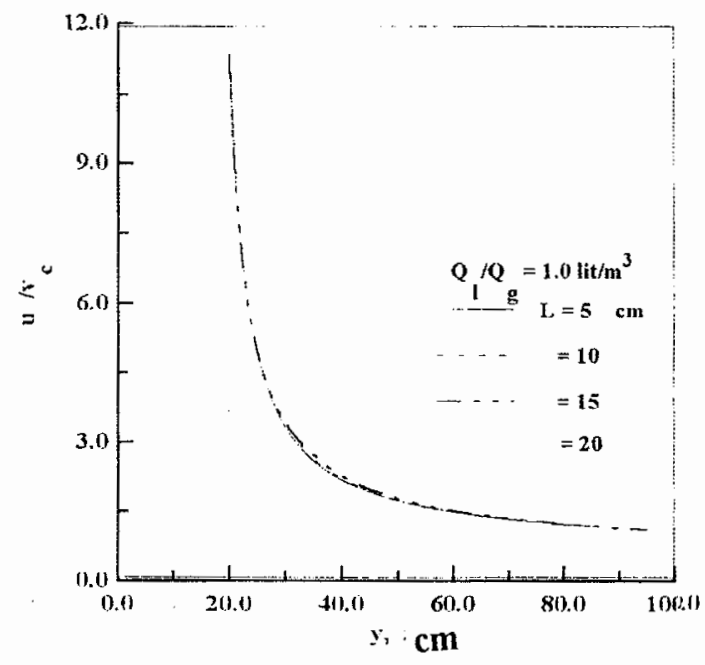

(c)

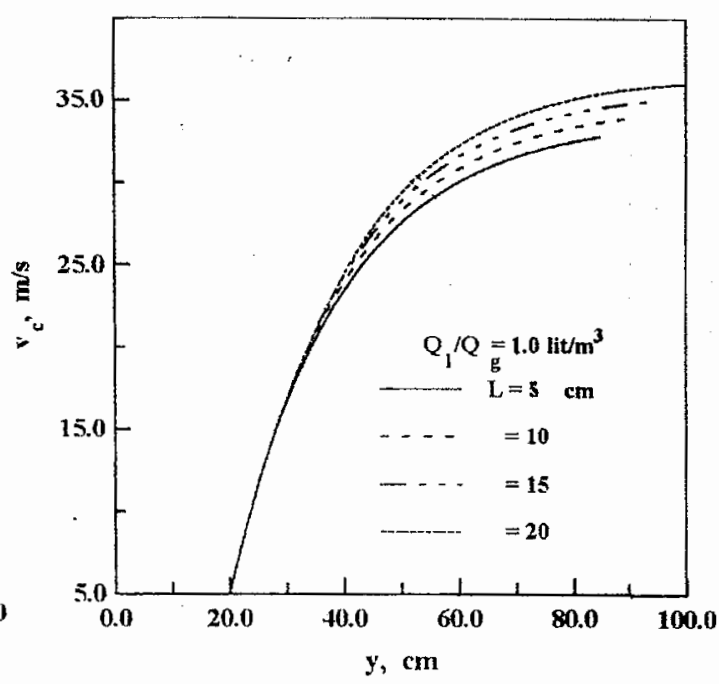

(b)

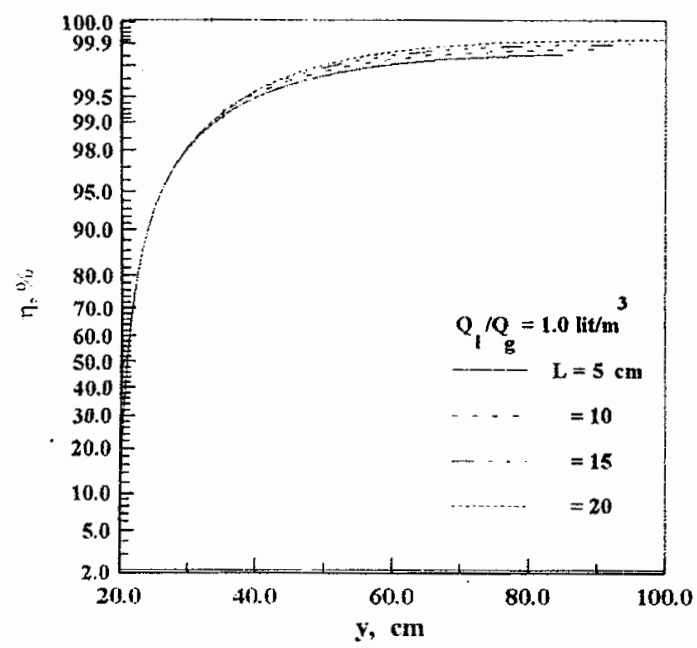

(d)

Fig. (4) Variation of axial pressure drop, droplet velocity, velocity ratio and scrubber efficiency along the scrubber axis at different values of throat length. 


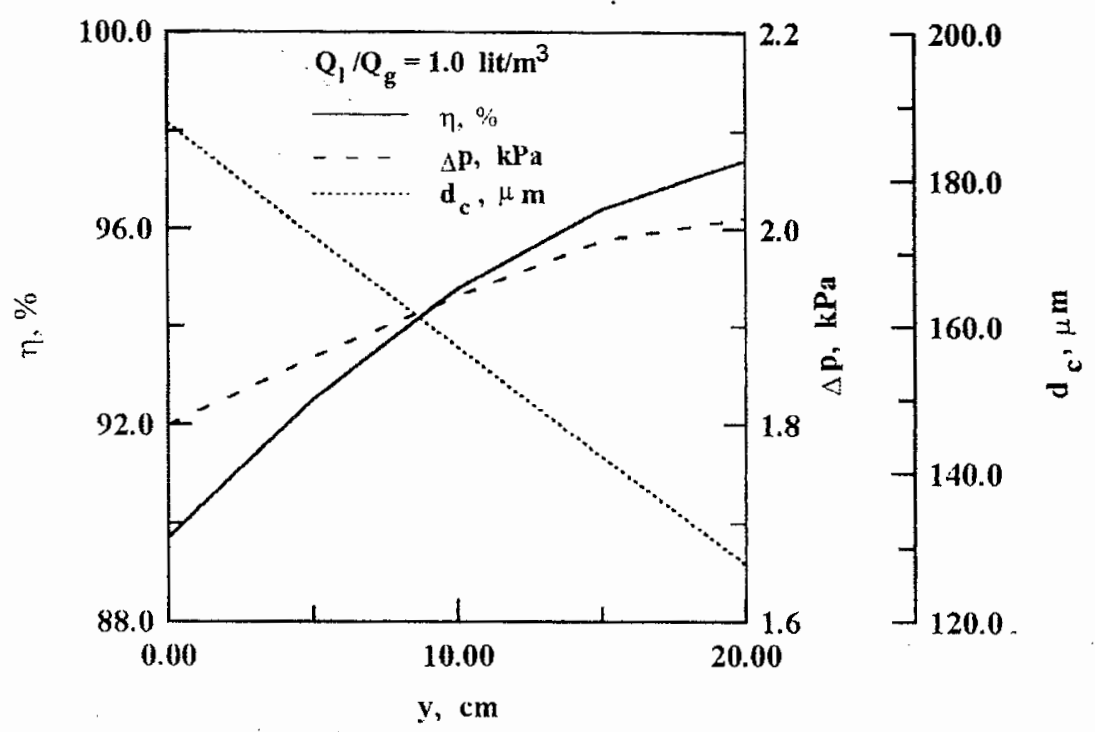

Fig. (5) Effect of injection position on the collection efficiency, pressure drop and droplet diameter.

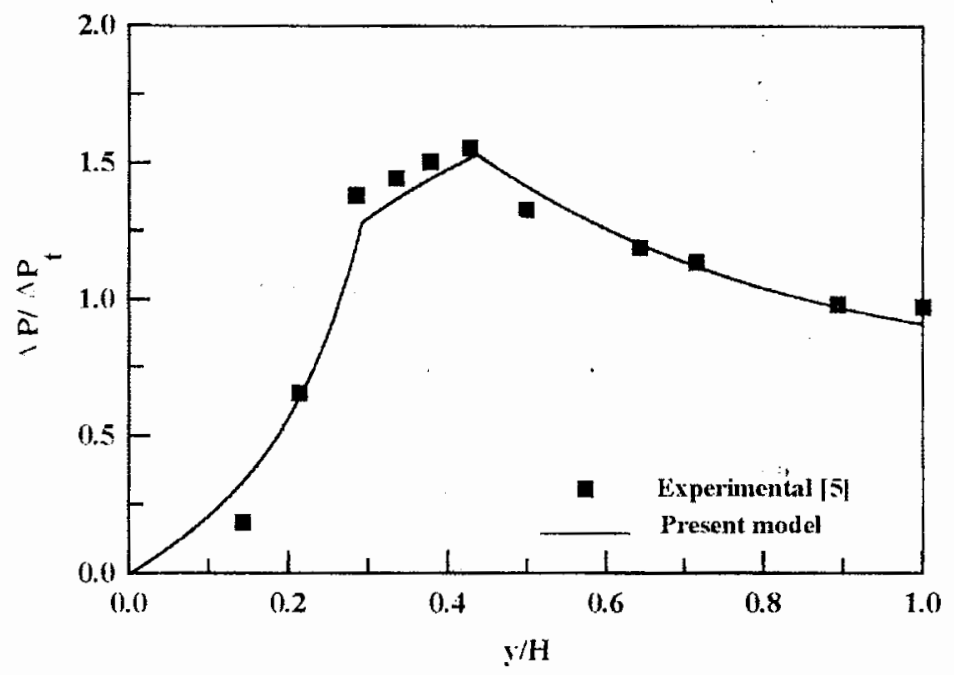

Fig. (6) Comparison between present model and experimental results, [5]. 


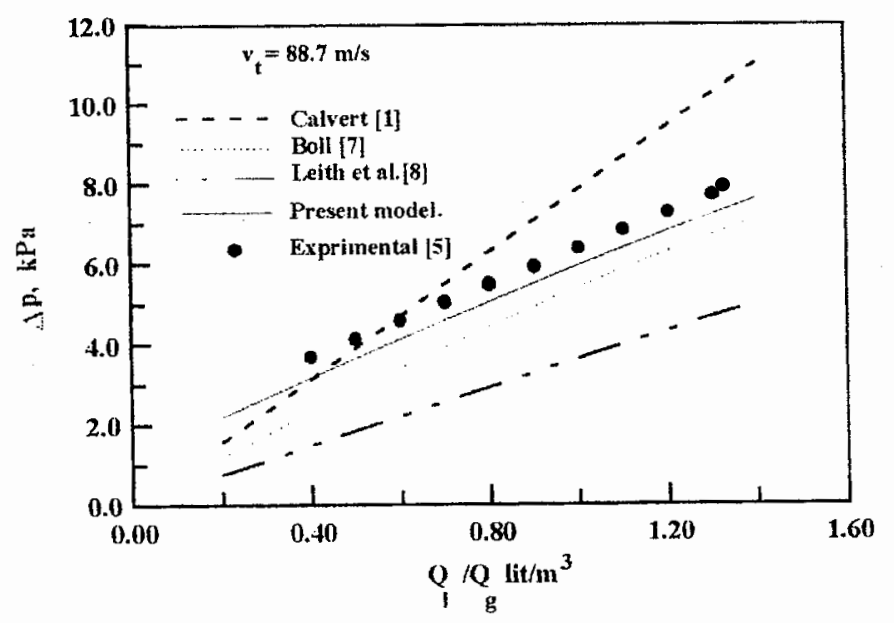

Fig. (7) Comparison of established pressure drop models with published experimental data and the present model.

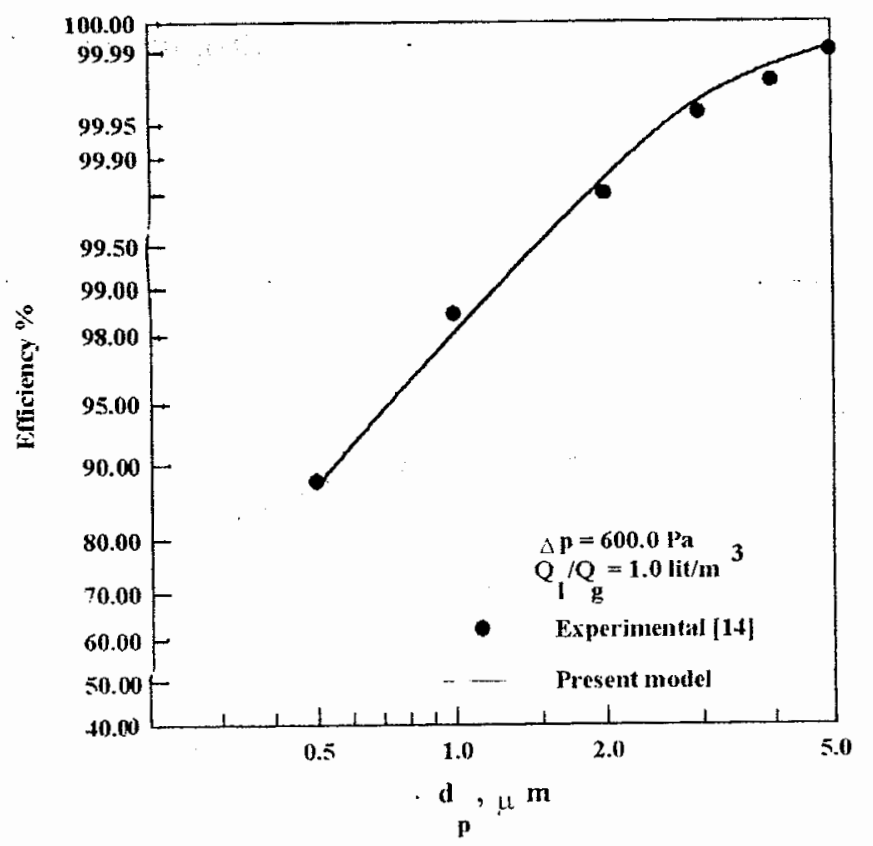

Fig. (8) Comparison of collection efficiency with published experimental data. 


\section{" التنبؤ بأداء جهاز فنشورى لتنقية الغاز "}

ميخص الثيتث:

يعتبر جهاز فنشورى لتنقية الغاز ات (Venturi Scrubber) أحد الأجهزة المستخدمة فـى تتقيـة

الهو اء و الغاز ات من الأثزبة والجسيمات العالقة بها بالإضافة الي استخدامه في امتصاص الغاز ات و الأبخـــــة

الضارة و المتصاعدة أثناء العمليات الصناعية و التى تتقاعل مع الماء. ويمكن وصف أداء جهاز فنشورى عنسد

استخدامه بمفدار الفقد في الضغط خلدل الفنشورى و كذا كفاءة التجميع للجسيمات (particles) من الغاز لمــا

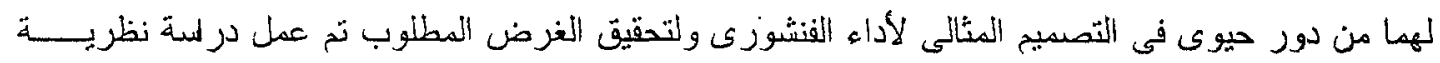

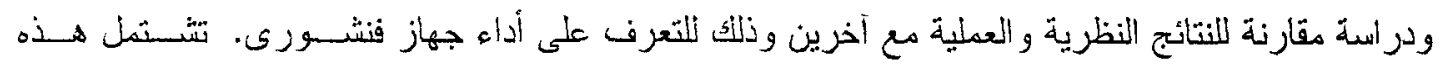

الدر اسة النظرية على موديل رياضدى لدر أسة هذا الأداء. و يصف هذا الموديل النظرى المعادلات التفاضليـــة

الحاكمة لكل من تركيز الجسيمات ، حركة القطرة ، تصادم الجسيمات وكذا تغير كمية الحركة. ويحتوى هـذا

الموديل أيضا على كيفية حساب كفاءة التجميع معتمدا على ميكانيكية وقوى كل مــن القصــور التــاتج عـن

الاصطدام ، الانتشار ، الثتاطع والاعتر اض ، قوى التجاذب الأرضية. كما يأخذ هذا الموديل فــى الاعتبـار

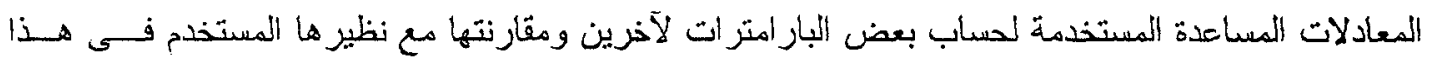

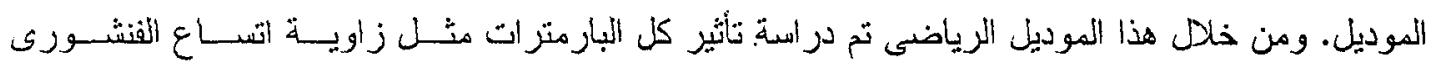

(throat (divergence angle, $\beta_{2}$ )

على أداء الفنثورى. وقد أظهرت هذه الدر اسة (injection position, y) وكذا مكان حقن الماء length, L)

النظرية زيادة كل من الفقد فى الضغط وكفاءة التجميع بزيادة طول عنق الفنشورى ونسبة الماء إلـــى الـــهو اء

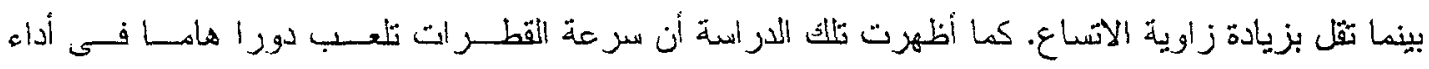

الفنشورى. ولاختبار صدة هذا الموديل الرياضى تم عقد عدة مقارنات بين نتائج البحث الخاصة بهذا الموديـلـ

و النتائج المعملية المنشورة لآخرين ، وكذا المتاثج النظرية المنشورة لموديلات أخرى. وقد أظهرت نتائج هـــا

الموديل أنها تعطى توقع أفضل لأداء الفتشورى مقار نة بالموديلات الأخرى . 